\title{
THE REVIVIFICATION OF INDIGENOUS IGBO TRADITION IN TESS ONWUEME'S THEN SHE SAID IT
}

\section{By}

\section{Dr. Aml Ibrahim*}

For centuries Africans had been subjected to a process of negation and marginalization through slavery and colonization at the hands of Europeans. Even their languages and cultural practices deemed inferior to that of Europe. Consequently, one of the most intellectually popular ideas in the African world, Afrocentrism is having an increasing impact on both the social sciences and humanities. Rooted in African culture, it challenges Western values and traditions to offer a new thought and framework able to confront multiple forms of oppression. The aim of this paper is to examine Tess Onwueme's play Then She Said It (2002) to explore its potential for creating a better socio-political milieu through reviving the indigenous Igbo heritage by * د. أمل إبر اهيم: مدرس الأدب و المسرح بقسم اللغة الإنجليزية ـ كلية الآداب - جامعة الفيوم (THE REVIVIFICATION OF INDIGENOUS... )Dr. Aml Ibrahim 890 
manipulating multiple techniques. This play is chosen for the study because it is far more than a play that delineates women's oppression in a patriarchal society; it vividly dramatizes the need for protest against massive corruption, abject poverty, exploitation and devaluation, especially at the hands of those entrusted to protect the people. Moreover, it reveals Onwueme's interest in reviving her ancestors' traditions.

Because Onwueme believes that female writers should not only write about women's issues, she has engaged herself with larger issues related to retrieving the conscience of the world. Winner of a prize granted by the Association of Nigerian Authors in 1985, Onwueme's dramaturgy covers issues of powerlessness, genocide, greed and inequality that plague human society at large though Nigeria was her primary setting. In an interview with Nubia Kai, Onwueme asserts that:

I want to see our women make more impact and be recognized in our society... We live in a society where women have it very hard. Their life is 
manipulated by others. So my consciousness, my own sensibility as a writer is to see change... so I have the girls finally revolt against the system in one way or the other. (3)

Throughout her dramatic career, she attempts to address issues pertaining to her Nigerian homeland in hope of transforming it into a democratic egalitarian society.

Then She Said It has frequently been analyzed as an ecofeminist and a feminist play. In his article "Eco-literacy and the Planetary Crisis: Nigerian Protest Drama and the NigerDelta Dynamics", Emmanuel Uzoji discusses the play as a commentary on the planetary crisis in Nigeria. He argues that the play depicts the harsh condition of the environment and its effect on women. In a study entitled "The Niger Delta Violence, Women and Ecofeminism", Samuel Jeremiah examines violence against women that has been fueled by environmental degradation. Moreover, Uwem Affiah writes an article entitled "Protest, Resistance and Activism in the drama of Tess Onwueme" to highlight woman's activism in a society which deprives her of sociopolitical rights. In a study 
entitled "Gendered Performance, Fluid Identities and Protest in Tess Onwueme's Then She Said It", Rowland Amaefula discusses the cross- gendered roles adopted by the characters in the play as a strategy of protest. His main argument is that Onwueme subverts gender stereotypes by depicting a transformation in the social roles assigned to both female and male characters in the play. To the best of my knowledge, the play has not yet been analyzed from an Afrocentric perspective, paying much attention to the techniques adopted for the revival of the Igbo tradition.

The paper at hand focuses on three techniques manipulated by the dramatist to revive the ancestors' tradition: the structure of the dramatic performance, the relation between characters' names and their identities and the interaction between actors and spectators. Therefore, my argument is based on the assumption that the revival of the Igbo tradition through using the aforementioned dramatic tools lies at the heart of Onwueme's Afrocentrism. This paper is based on the hypothesis that Onwueme presents an African experience in her play inspired by Afrocentricity through reviving the Igbo tradition and employing her dramatic techniques in an 
attempt to offer solutions for the current socio-economic problems challenging her community. The paper attempts to answer the following questions: What are the Afrocentric aspects in the play? How does Onwueme revive the Igbo traditional heritage? In what way is the structure of the play influenced by the traditional Igbo performance? How are the characters' names reflecting their identities? How does the dramatist achieve actor/ audience interaction? To achieve its objective, the paper starts with a brief overview of the definition of Afrocentricity, with the aim of offering analysis of the revival of Igbo heritage in the play.

\section{The concept of Afrocentricity}

In his seminal work The Afrocentric Idea (1987), African American scholar and activist Molefi Kete Asante contends that Afrocentricity as a theory deals with

The ideas and events from the standpoint of Africans as the key players rather than victims... it is Africa asserting itself intellectually and psychologically, breaking the bonds of Western 
domination in the mind as an analogue for breaking those bonds in every other field. (172)

According to Asante, Afrocentric philosophy empowers African people and helps them to assert their individuality. It has gained a wide appeal worldwide since it entails a remedy for the African dilemmas. There are a number of definitions of the term Afrocentricity: it can be viewed as "African centeredness" that places much emphasis on Africans' distinctive identity (Chukwuokolo 32); it is also viewed in terms of a unifying entity the binds the methods of African and African-American studies for ideological purposes (Early 44). Another definition stresses the idea that Africanness is an ensemble of ethics (Stikkers 40). Mazama affirms that Afrocentrism "rests on the assertion of the primacy of the African experience for African people. Its aim is to give us our African, victorious consciousness back" (388). Restoring African consciousness and deconstructing the concept of Eurocentric universality is what binds all these definitions. When Africans see themselves from an African rather than from a Western perspective, they view themselves as subjects and agents who are able to resist the 
marginalization process. As a powerful ideology, Afrocentricity stresses the importance of restructuring African lives in a positive sense away from the chaos of Westernization. Onwueme in Then She Said It employs features from the African heritage that lies at the centre of African people's lives to create order in a fragmented society. As an advocate for the notion of Afrocentricity, she argues that since "chaos and incoherence define the modern state; the artist must not abandon his heritage but must strive to salvage it" ("Visions of Myth" 63). Consequently, she resorts to the dynamic African classical past as a liberating tool that would help in the betterment of the entire African society.

Asante deplores the fact that Africans "do not exist on [their] own terms but on borrowed, European ones" (387). The gap of the missing African paradigm is temporarily filled with a European one. Nevertheless, Asante does not imply that Afrocentricity is the antithesis of Eurocentricity as he calls for a peaceful co-existence between all cultural paradigms. Therefore, Onwueme deploys her dramatic tools to focus on resurrecting from the past an African tradition 
that reflects the rich heritage to create a better future. For Asante, African art is a communal process shared by both the artist and his audience to achieve "the totality of an experience" and for the purpose of interpretation (79). In order to reach this communality of experience, Onwueme delineates the collective protagonist, not the single hero and stresses the role of spectators as active participants rather than passive observers of the performance. Her aim is to stir the indigenous citizens out of passivity and reluctance.

Paul Gilory objects to idealizing Africa as motherland since it implies the division between Africa and the West. Contrary to Gilory's accusation cited in Yogita Goyal's book that Afrocentrism is based on "the romantic idealization of Africa" (225), Onwueme's Afrocentric perspective highlights the celebration of African roots that works out as a mechanism for resisting both patriarchal and neocolonial hegemony without idealizing Africa. This is evidenced in waging a direct attack against the complicity of some African leaders with the neo-imperial power structures. Adherence to the rituals of her native Igbo cultural heritage helps the dramatist to find solutions for the persistent problems, enact 
positive transformation and empower her community. In his seminal work "Black Studies and the Problematic of a Paradigm", Karenga has identified some major features of Afrocentricty such as harmony with nature, a high level of spirituality, the unity of being and respect for the ancestors (402). These characteristics will be examined in relation to the techniques adopted by the dramatist. Afrocentricity constitutes an appropriate perspective to analyze the play at hand because it comprises the Igbo's national traditions that Onwueme attempts to revive. It embraces a veritable mine of artistic tools manipulated to explore the past, reform the present and improve the future.

\section{Tess Onwueme's Revolutionary Theatre}

As a leading African female playwright, Onwueme's theatrical oeuvre is marked by a quest for change through activism and revolt. Nwachukwu- Agbala convincingly maintains that, "we observe in Onwueme's dramatic corpus an artistic desire to change the status quo through the ridiculing of the obnoxious in our tradition as well as by exposing the political and economic conditions in the 
society" (467). Through criticizing African societies and her constant engagement with mythical African traditions, Onwueme not only exposes the present entanglements but also suggests remedy. Although her plays are open- ended, she shows her audience the catastrophic repercussions when change is met with resistance giving them the chance to draw their own conclusions amidst a heated debate. In order to reform her society, Onwueme resorts to manipulating rituals and myths attached to her Igbo society. In the Proceedings of the First International Women Playwrights Conference, She forcefully asserts:

It is our prerogative as legatees of these truths to use them and make them relevant to our own situation... Myths sure there, the beliefs are there; the traditions are there. It is our duty as writers to raise the consciousness of our people to see new visions for their times. (107)

Traditions and myths are the cornerstone of Onwueme's theatre. Embarking on aesthetic theatrical strategies that manipulate spark dialogues, movements, powerful images, 
songs and dance, she generates a wide response and delineates a possibility for a better future. In the 1988 Conference, Onwueme asks all women dramatists to "commit [themselves] to retrieving the conscience of the world, the conscience that is drying up each day" (xviii). She is particularly keen on deconstructing the negative stereotypical images associated with African women and the construction of an empowered woman's subjectivity. According to Glenn Odom, "Onwueme, who lived in Lagos for a large portion of her childhood and adolescence, is well versed in Yoruba and Igbo culture, and, as such, embodies the kind of assimilation that is core to both Yoruba ethics and government" (110). An Afrocentric perspective to Then She Said It attempts to reveal how Onwueme makes proper use of her Igbo cultural heritage in urging her audience to denounce neocolonial power structure.

\section{The Structure of the Dramatic Performance}

Onwueme follows the methods of the traditional Igbo performance which begins with the 'juba dance' and entrance song, followed by the 'revue', and the 'finale' (Adedeji 262). 
She significantly divides her play into twelve movements, interrelated by a common motif, in which the events are presented alongside dances and songs in a manner that echoes the traditional 'revues'. Moreover, the twelve movements coincide with the movement of water in The Niger and Benu River and with people's movement from the square market to the oil club. Symbolically, these movements stand for the steps followed by protesters in Hungeria in their way to liberation. Besides the movements, the play has a prologue and an epilogue. Onwueme has not totally abandoned the devices of Greek drama, but she dexterously constructs them in a way that links them to her national culture. In her revival of the indigenous Igbo tradition, she merges its elements such as music, songs, dance, miming and clothing with Western techniques such as the chorus, the prologue and the epilogue. By adopting a more tolerant attitude to Western values, she manifests that there is no conflict between Western theatrical premises and traditional Igbo cultural practices. This proves that Afrocentrism does not replace Eurocentrism but it offers a wider perspective and multidimensionality.

(THE REVIVIFICATION OF INDIGENOUS... )Dr. Aml Ibrahim 901 
Onwueme's Then She Said It delineates the Nigerians' resistance to authoritarian practices and their protest against environmental decay and social corruption caused by neoimperialism. The downtrodden citizens suffer because "multinational oil corporations prefer to import laborers from rival communities or distant lands rather than create jobs for communities most immediately affected by extraction operations" (Nixon 71). The play starts with the prologue where a cluster of auditory imagery are manipulated to shed light on the suffering and humiliation youth and old women in Hungeria are subjected to at the hands of the armed men. We find "a strident drumbeat", "gun-shots", "explosive sounds", "war-drums", "angry voice", "shrieking sound", and "thick shrouds of silence" (1). In spite of being a literary device borrowed from Greek drama to establish the setting and give background details, the 'prologue' is creatively integrated into the African context by manipulating the chorus to perform three stunning functions: beating the drums, miming and dancing. These functions are deeply related to the Igbo tradition. In this sense, Onwueme does not disregard the Eurocentric tradition as she merges it with the 
traditional African heritage to achieve a peaceful coexistence between them.

By exhibiting how the Igbo people used to entertain themselves with dramatic performances, the dramatist emphasizes the past and aims at preserving the African culture. To dramatize their experience, the unified African people set up the stage, dress up, mime, and adjust to their new characters. Meanwhile an explosive sound is heard and they have to run in different directions. Okodo explains the nature of traditional Igbo performances, "Such performances are rituals, masquerades and masquerading, music and dance, wrestling, outing ceremonies and festivals" (132). In a formal Igbo opening, the play starts with an entrance song chanted by the young women to support and comfort each other. The dramatist deploys music and dance to exhibit some cultural aspects of Afrocentricity. Because the juba dance has a purgative effect, the protagonists practice it regularly. Though interrupted when frightened youth and wounded old women come shouting for help, the spiritual/blues song binds the Africans to their spiritual world. This reminds us of Karenga's assertion that "a high level of spirituality" is an 
essential attribute informed by Afrocentric consciousness (402).

The plot of Then She Said It is situated in the imaginative world of Hungeria (i.e. hungry land), a metaphor for Nigeria where we find two significant places: Gra/Oil Club where rich dwellers inhibit the locale and the market square where the majority of the down trodden are suffering abject poverty. The sharp contrast between the two locations cannot be ignored. When the play opens, the rural setting of the Niger delta has been destabilized. The audiences are confronted with a chaotic situation in which the military is indistinguishably killing and silencing people's voices that revolt against the dilapidation caused to the ecosystem. Rob Nixon maintains that "the European powers and the United States denied newly independent states resource sovereignty by declaring that such resources were not national in character but belonged to all humanity" (70). The indigenous inhabitants confront neo-imperial practices that have caused suffering for both humans and non-humans. 
Movement One introduces the powerful allies: Atlantic (the foreign director of the oil club), Kainji (the national government official of oil), and Ethiope (the traditional Chief) playing monopoly game in the Gra/oil club. The dramatist here implies that their major concern is the acquisition of money. In this first revue, the characters are depicted as types. As Adedeji puts it, the revue expresses "the prevailing characteristics of stereotypes rather than specific individuals" (261). All three characters depicted in the revue represent the stereotypical corrupt authority that misuses its power to humiliate innocent people. They embody moral degeneration, greediness and materialism since they drink alcoholic drinks; poke their "greedy eyes" into Oshun's body while she serves them and Atlantic "sends his hands to work and wander around her willing body" (3). When they start discussing the death of thousands of African people due to drilling oil and the unsafe pipelines, Kainji blames the Africans themselves because they enter into what is marked as 'restricted area' and Atlantic mockingly responds, 
Now I understand the true spirit of the Organization of African Unity. Quite a great specimen of ritualized Organized Assassins' Union... Let's celebrate the organized animals' united genocide! It's the great tradition of being born-again-African... bloodbath... drink to Africa's united planned progress in genocide! (6)

The politically satirical tone can easily be discerned in Atlantic's speech. Onwueme offers a critique of the African Unity Organization that remains silent while thousands of innocent African souls are killed and subjected to genocide at the hands of multinational companies that seek profit in the African lands. The first movement ends with the protesting mob approaching the oil club with their drumbeats calling for their rights of getting their land back and controlling their resources. The stage directions vividly depict the awesome scene:

The crowd gets more agitated, amplified by the chants, into a marching tune. At first, their voices and chants are discordant, but as they begin to 
march and face the direction of the Gra/oil Club, they find harmony and the tempo rises until they move, surge forward in angry uproar toward the exclusive villa. (9)

The agitation of the crowd accompanied by musical tunes and chants raise the tempo of protest and draw a ritualistic image of an out breaking revolution.

Movement Two moves to the market square to delineate the dehumanization of African people exemplified by Oshun and Obida who come to the petrol station to buy fuel and kerosene for their daily domestic use. It is a pathetic situation that Hungeria produces oil and at the same time its people are suffering from the scarcity of petroleum products. Because African resources are plundered by neo-imperialists, African citizens suffer a life of abject poverty. Consequently, Oshun, compelled by socioeconomic pressure, steals soap and toilet paper from Kainji's villa. Onwueme launches a scathing criticism on some African people by focusing on how they indulge in theft and human trafficking to get revenge from the people who oppress them. In this sense, Onwueme's 
afrocentrism is not marked by a romantic or idealistic view of Africa; rather it entails a sharp critique against all social ills in the African community.

Movement Three continues the dramatization of Oshun and Obaida's suffering to get fuel since the sign reads "No Fuel" (14). They join other Igbo women and men who try to pump the empty fuel hose. However, the policemen arrive with their whip and many people are arrested and handcuffed. The reference to the way they push the crowd backwards and fire them with tear-gas unmasks the violent mechanisms and the power abuse in Nigeria that Onwueme tries to reform.

Through verbal theatrical mechanisms, Movement Four highlights other social ills such as the violation of poor villagers, unemployment, rape and killing at the hands of foreigners. The brutality of the police and the tyranny of profiteers are also dramatized in this movement. Through using Nigerian accent and slangs in the dialogues between characters in the play, the dramatist adheres to the Igbo tradition that binds the Nigerians to their native culture that 
endows them with the ability of protest and self-expression. Niger's following speech provides a good example: "Dis pickin. No push me-o! I get motor? Na ordinary kalozin me I wan buy-o!" (16). This quotation unmasks Niger's objection to being ill-treated by the police who push the crowd and beat them with a whip. The use of words and phrases related to dialectical origin is quite common in the play to reinforce key ideas and achieve artistic objectives. Moreover, because "the only way of writing good Igbo is by forcing strings of proverbs down the throats of readers" (Emenanjo 58), Onwueme cares to use many proverbs and idioms to revive the Igbo tradition and reveal the protagonists' defiant attributes. Niger's speech: "Can you catch an old hen with mere chaff?" (14) and Benue's speech: "the fierce dry harmattan wind will lick [your lips] for you" (77) provide a good example.

From Movement Five to Movement Eight the dramatist offers a sharp critique of the complicity of Ethiope with the neo-colonial power represented by Atlantic. In traditional performance, the strangers usually represent the Western imperialists and they are attacked in sketches. Adedeji 
argues, "These are sociological types which divide sharply into the stranger and non-stranger elements" (61). Strangers in Then She Said It are represented by neo-colonial powers, corrupt government officials, oil agencies, profiteers, and unjust authority that have usurped the land's natural resources.

In Movement Seven, Onwueme depicts how the African protesters empower themselves through chanting and trying to open the oil club's gate with their bodies. In a frightening spectacle "the mob continues their pleading and chattering outside" and some of them are wearing masks (59). Chike Aniakor argues that

As a grand artistic display born of the economic fruits of the soil and as the highest manifestation of the achievement and social distinction of an Igbo community, the mask unites the people in their pride and in their sense of historical continuity with the ancestor. (42)

In a traditional Igbo performance, characters wear masks that denote their dominating attributes and exhibit their 
distinctiveness as a community. Therefore, these masks are used by the dramatist as "an extension of the personality of the dramatis personae" (Adedeji 61).

Karenga's contention that harmony with nature is one of the basic aspects of Afrocentrism is conveyed in the play through Onwueme's engagement with restoring balance to the relationship between man and nature through criticizing the ways by which global corporations working in oil exploration have destroyed the pastoral life. The excolonizers have caused land infertility, oil pollution, the destruction of fish and sea life and the scarcity of clean drinking water. Obida and Niger's following dialogue sheds light on the deteriorating situation:

Obida: They've killed everything with their pollution and oil spillage. We cannot breathe clean air. Fish die or get fried in the simmering rivers. Water- water everywhere. But we have no clean water to drink! And now we have no land too? 
Niger: No firewood because the plants and trees are soaked in oil. What do they expect us to cook with? (15)

In this excerpt, Onwueme's Afrocentrism is culminated in her depiction of the plight of the villagers in her country as a result of neo-imperialist systems. The devastation of trees is considered a disaster since they represent the attachment of the villagers to their rural environment which is being lost through imperialism. The dramatist reprimands the exploitative multinationals held responsible for the ecological crisis threatening the life and existence of the villagers. She represents the people who are undergoing multiple forms of suffering due to the malevolent influence of oil contamination. In his seminal work Slow Violence and the Environment of the Poor, Nixon asserts that pollution that affects both nature and humans is an act of "slow violence", i.e. "a violence that occurs gradually and out of sight, a violence of delayed destruction that is dispersed across time and space" (2). By disrespecting the laws of environmental protection, exploitative multinational oil companies have not only abused the environment but also 
violated the lives of pauperized people. Frustrated by the situation, the villagers have found themselves plunged into abject poverty, violence, armed robbery and kidnapping.

Since Afrocentricity suggests remedy for the African people's deplorable conditions, Onwueme stresses it in her reference to sisterhood and solidarity among African women in Movement Nine. The following dialogue foregrounds binding all the oppressed as a unifying mechanism for African women to survive:

Benue: So daughter, tell us. How should we fight?

Chorus of Women: How are we going to fight their guns?

Obida: Our soul. United...

Koko: Again she said it!

Chorus of Women: Our souls! Our spirits! Fight! Fight! (79)

The Mothers and daughters of the Niger delta find their way clear in the midst of trouble; they recognize that their liberation and Afrocentricity rests upon their adherence to 
their cultural experience that unites them. This goes in line with Karenga's notion that "the unity of being" is placed among the main Afrocentric aspects informed by the Afrocentric consciousness (402). Since they share the same experience of deprivation and victimization, the African protesters fearlessly decide to unite against corrupt government and oil companies. Merged into one entity, their chant is accompanied by the drums of the Congo music played by Obida to "electrify the crowd" (79). The stage directions describe how communal music-making and songs of their Igbo tradition motivate them: "They embrace each other. The women break into song and serenade" (79). Onwueme advocates sensitization, activism and protest among African people to stop injustice and achieve social transformation for their benefit.

The last three Movements build up the dramatic tension since they present the collective action taken by protesting women and youth to denounce the neo-colonial hegemony. Onwueme delineates how they transformed into rebellious purveyors of protest by killing the director's dog, and kidnapping the oil director. She sticks to the conventions of 
the Igbo masquerade performance that comprises exchanging characters' roles and wearing masks; these in part can be attributed to the nature of the venues in which traditional performances took place. The characters exchange their roles during their march towards the oil club which is always accompanied by songs, Igbo choral music, war drums and dance to conjure the holy spirits of their ancestors to empower them. Odon maintains, "The spirits can only appear when the drum calls them, and thus the dance is linked to the appearance of the Gelede masques in a profound way" (116).

In movement twelve, the women who were violated in the past are healing their wounds now by taking revenge from their ex-colonizers. United and empowered, they attack Atlantic. Then they speak their charges against Atlantic and the government official to the judge in the court. The play's final Movement demonstrates that the collective will of the mass populace can never be defeated when Atlantic and the chief ask for forgiveness. However, in the play's epilogue, Ethiope assumes a new role as the Trial Justice. Onwueme implies that his new role is not different from the role he

(THE REVIVIFICATION OF INDIGENOUS ... )Dr. Aml Ibrahim

915 
played before since both roles are inflicting more pain on the protestors. This conglomeration of roles suggests that no linearity is established between the play's movements and gives a distinctive African flavor to the epilogue as a Western device to celebrate Nigeria's cultural tradition. Stage directions read "Masked, Atlantic now plays the General here. While Oji plays the First Police. Obida and Oshun can play the role of the Second Police"(92). Role reversal and new attributes endow women with subjectivity as Onwueme here offers alternative roles for the performers to choose. Manipulating this strategy marks another creative endeavor to merge the epilogue with a traditional Igbo dimension. The mob can now identify their enemy as they run towards the oil club. Another crucial transformation takes place when Oshun gains awareness; she leaves prostitution and joins the demonstrators to stop the commodification of both women and land. As it appears from the incidents of the play, Oshun goes through a spiritual journey during which her personality develops from ignorance and dependence to knowledge and independence.

(THE REVIVIFICATION OF INDIGENOUS ... )Dr. Aml Ibrahim 
The play's resolution is reminiscent of morality plays in its didacticism and straightforwardness. This reveals Onwueme's concern to deliver a direct moral message to her audience. Odon asserts that, "people watched these shows because they got something from them, and ethics are one of the primary things on offer in this style of theatre" (114). Odon here strikes our attention to the fact that the motif of the Igbo tale is meant to be a moral fable that enhances didacticism. In an idealistic 'finale', Onwueme depicts the government on trial and Atlantic's cowardice is revealed in his dialogue with the government official, "I'm finished... hold me... we're finished" (98). Onwueme's Afrocentric role as a culture preserver derives her to depict a didactic message since vice is punished and virtue is rewarded. The play ends with the final dance accompanied by traditional songs that echo a truly traditional mode of performance.

\section{The Relation between Characters' Names and Their Identities}

"While it cannot be claimed that names are invariably reliable cues to information about their bearers" (Brennen 
142), the characters' names in Then She Said It are highly suggestive. The dramatist manipulates them as signifiers that stand for some signs. In this play, almost all the characters' names are drawn from names of rivers in Nigeria, hence they are endowed with agency, echo nature and embody dynamic change. Moreover, they bind the villagers to their past tradition. Since it is a source of life and survival for humanity, water is personified in the play. In her notes to the introduction of the play, Onwueme states that "all the fictional characters in this play are named after rivers or bodies of water, both big and small. While the smaller waters act as youths, evolving and changing roles, the bigger ones remain constant, even in their dynamic change of course" (ix). The implicit message is that the play deals with a national subject matter. The dramatist utilizes her dramatic techniques on a symbolic level to present a form of drama that tackles persistent problems in her native country and revives the traditional Igbo cultural practices.

The villagers cannot live without their rivers to irrigate their lands and provide them with nourishment. The Niger and Benu River, two main sources of water in the Niger

(THE REVIVIFICATION OF INDIGENOUS ... )Dr. Aml Ibrahim 918 
Delta, are personified and represented as mothers who initiate the resistance against corruption and injustice. Standing for tradition, these rivers are given a human configuration marked by Afrocentric character traits such as adaptability and flexibility that enable them to assess their negative circumstances and attempt to find solutions. The protagonists Niger and Benue exhibit a powerful characterization as they attempt to protect their childrenOshun, Koko and Kainji-from negative consequences of neo-colonization and corruption that plague Hungaria. Since they are respected by all the villagers, this goes in line with Karenga's assertion that "veneration of ancestors" and "respect for tradition" are among the main Afrocentric features (402). The metaphorical representation of nature as dynamic and alive intertwines man and landscape and asserts the Afrocentric ideology that man is in harmony with nature. Niger says: "It is I, I Niger, the umbilical cord, running all through these coasts from here to the Fouta Djalion Mountain that speaks" (88). Throughout the play, she constantly remains self-assertive. 
Furthermore, in traditional Igbo culture, the name Oshun refers to goddess of Oshun River or goddess of love and sweet water. Oshun is strong-willed and ambitious but due to the harsh circumstances surrounding her she has become Atlantic's mistress. She exhibits attributes of genuine sisterhood as when she has access to the oil club; she brings some household items and shares them with her friends. Through focusing on the dilemmas confronting female characters such as Oshun and Koko, the dramatist highlights prostitution as one of the cataclysmic impacts of land devastation and women exploitation. Though educated, Oshun and Koko remain unemployed in a devastated environment and their poverty has forced them to choose prostitution to sustain their lives. Nevertheless, the revolutionary voices we hear out in Then She Said It are women's voices who insist on "retaliating" to reclaim their humanity and protect their land:

Women: Go fight them now. Fight the oil club! Fight! Fight them. Fight them who are against us. (60)

(THE REVIVIFICATION OF INDIGENOUS... )Dr. Aml Ibrahim 920 
In this sense, Onwueme is not concerned with highlighting women's objectification in a patriarchal society; rather she is more engaged with the stamina and collectivism of her Igbo people that motivate them to confront and change their sordid conditions. Uchendu asserts that, "the Igbo believe that these social calamities and cosmic forces which disturb their world are controllable and should be manipulated by them for their own purposes" (11).

Significantly, the name Obida is of Igbo origin too and it means 'devout worshipper'. Empowered with leadership qualities, her spirit is energized to fight against the oppressors. Obida says, "To subdue our enemies. We must learn their own art...Go under, know their secrets and then act when they least expect it" (97). Endowed with defiant attitude, her plan to liberate her people necessitates learning the secrets of their common enemy. While Oji is named after River Oji in the Niger Delta region, Kainji is named after a lake in Nigeria. He works as Atlantic's guard and is depicted as an aggressive and proactive person. He represents the government official in the play who carelessly says: "Who cares anyway? The oil pipelines are clearly marked 
'Restricted Area. Out of bounds to all unauthorized persons'. But no, they are blind. Deaf. What were they doing there, anyway?" (9). He holds the villagers responsible for the catastrophe describing them as "lazy bastards" who should not be trusted and accuses them of stealing oil. Due to the collaboration between corrupt local authority and neoimperial foreigners, no serious measures have been taken to deal with the excesses of the oil companies in the region. The villagers' lives have always been full of continuous conflicts first by colonization and then by transnational companies.

Named after the Atlantic Ocean, Atlantic stands for the white Western or multinational corporations that steal the country's oil wealth and insatiably seek profit at the expense of the pauperized African people. The name of this fictional character provides the play with an international dimension. He points out to the government official, "The look of hate and suspicion in these people's eyes. Even the domestic servants who work for you! The tone is changing here. I used to be much more comfortable. But these days. These youths? And even the women" (49). Though displaying distrust and hatred, Atlantic's speech sheds much light on the villagers' 
transformation into agency and rebellion. Ethiope is the stereotypical greedy local chief. He stands for a traditional tyrannical ruler whose conspiracy with foreign investors to get personal gains at the expense of the well-being of the Nigerian ecosystem and the common masses who were turned into "disposable people" (Nixon 71) is highly criticized in the play. Onwueme evokes protest against this character type particularly because he sells his female relatives as sex objects to the white expatriates in exchange for money.

In contrast to the specific characters' names of Igbo/national roots utilized in the play, we find characters with collective names like 'the chorus', 'a woman', 'women', 'youth', etc. who stand for the downtrodden, to illustrate how their stereotypical lives are filled with oppression. They are presented as an oppressed social group kept in what seems to be a refugee camp where there is "No running water yet. No light. No amenities. Diseased. A cesspool of epidemics. Cholera deaths rising" (49). Silenced and marginalized, they are denied basic amenities such as electricity and clean water. They are suffering from incurable diseases too or what 
Nixon calls "displacement without moving" (71). He points out that, "the loss of the land and resources beneath them, a loss that leaves communities stranded in a place stripped of the very characteristics that made it inhabitable" (19). Nevertheless, the nameless characters that represent ineffectiveness, powerlessness and passivity in the play's prior movements have been transformed into agents and activists near the play's end. When they become organized for protest, the dramatist refers to them as 'the crowd', 'chorus of voices', 'angry voices' and 'mob chorus' to imply empowerment and activism (61-67). The stage directions describe their collective action, "They sing, circle until blackout" (67). The protagonists resort to protest as their collective survival strategy.

\section{Audience Involvement}

Situated within the African context, Onwueme's theatre offers the audience more than a place for entertainment; it presents an interactive communal experience where humans, spirits and gods are involved and ideas are shared. Onwueme breaks down the fourth wall between the actors 
and the spectators to guarantee a collaborative theatrical experience. In her Three Plays, she argues, "When you break that fourth wall, then there is participation ...It becomes a communal effort. Everybody becomes a part of it"(12). Traditional Igbo performances used to take place in central places such as markets, squares, and yards. To quote Adedji, "the acting area or locale is always a circle around which the spectators crowd" (62). To avoid total estrangement, Onwueme chooses two traditional settings for her play: the square market and the oil club. By offering no scenic details or rigid specificity of locales, she offers her audience a freer stage atmosphere as in traditional performances. The following stage directions describe the uncomplicated familiar atmosphere:

The action begins now at the center of the village market-square. The space looks bare, tired and sleepy, except for the glowing crescent moon, hanging in one corner of the dominant blue-grey sky. (1) 
In order to make her play effective, she skillfully makes her audience an integral part of the dramatic performance by removing barriers between them and the performers. The stage directions foreground this fact, "There are no solid structures to inhibit the flow of people's movement" (viii). When characters act various roles and assume multiple contradictory identities, this gives them the ability to express all emotions corresponding to such roles. The effect is that the performer will not be identified with one particular role or the emotion pertaining to it. No one dominant mood rests for a long time to influence the spectators due to continuous shift from one mood to another. This technique helps the dramatist to provide her audience with various versions of the same story or multiplicity of perspectives. In other words, by inverting the costumes, the actors bring about various social and moral views to the foreground. Moreover, it rouses the audience's consciousness to the fact that the theatre is a world of imagination and the story presented is merely a play performed by actors; i.e. Brechtian alienation effect. The following stage directions provide a good example:

(THE REVIVIFICATION OF INDIGENOUS... )Dr. Aml Ibrahim 
The young woman quickly exits behind and returns with a box- full of clothing, house-hold items and whatever else is required to dramatize their experience. The people are so animated as they dress up for their new roles. Thus transformed, some begin to mime and adjust to their new characters, while others set up the stage. Once the stage is set, they quickly form a human chain, pounding the earth with their feet. (2)

One can argue that multiple role playing decreases emotional identification with the characters on stage. Nevertheless, by staging widespread abuse and suffering of the Niger Delta people at the hands of repressive powers, Onwueme uses traditional character identification too in her play to evoke the audience's emotive response to the characters. For example, the portrayal of the continuous gunshots and the heavy military bombardment unleashed on the villagers convey people's vulnerability and their deservedness of sympathy from the spectators. Therefore, she fuses Brecht's distancing devices with empathetic 
character depiction. Her goal is to present protest as a viable weapon against corruption and exploitation.

Onwueme utilizes traditional elements embedded in the Igbo performance such as the masquerade performance, traditional songs, drumbeats and dance to enhance communication and ensure audience's participation. She deploys traditional songs to stir her audience's memory and generate rapport between the performers and the audience as in traditional oral performances. The rounding-off-songs are strikingly situated in the majority of the play's movements to ensure a wide range of audience interaction and counterbalance the monotonous effect of the dialogue. The choral chants provide insights into the moral or ethical position of the presented story and generate discussions on current issues pertaining to their society. The stage directions describe Obida's improvisation of "her new anthem or national pledge" which she recites with her friend (25).Obviously, national songs are manipulated to celebrate the African national identity and prompt audience's deep emotional involvement. The audience is expected to awaken their sense of national pride and loyalty in response to the 
songs that remind them of their ancestors' heritage. Moreover, the dance represents an expressive body language and rhythmical physical movements used by performers to represent mystical elements and supernatural powers corresponding to traditional African heritage. For example, Obida in movement nine chants in the market square invocations "to her ancestors to rise up and come to their aid" (76). By conjuring the ancestors' spirits, the performers urge the audience to adhere to their traditional cultural values. Another interesting example is when the chorus was marching to the oil club to kidnap the oil director in movement nine, "their voices rise in song once again as they quickly march... The air is filled with the noises/ sounds of frightened animals, followed by crashing sounds, dogs barking, a clap of thunder, with lightning flashes" (86). By increasing anticipation, these special effects make the audience part of the performance; hence emphasizing the communal experience.

As in the traditional Igbo performance that used to involve members of the community, Onwueme aims at prompting the audience to search for motifs in the story by 
utilizing gestures, body movements and non-verbal communication. For example, the dramatist manipulates visual gestures by referring to Obida's "military steps" followed by the chorus as "they sing and dance in circles" to assert that nobody can silence their drums. Another example is provided in the description of the protagonists' reaction to the chorus's songs as "their feet step up. They hold each other and break up into two concentric circles; the daughters on the one hand and the mothers on the other. Oshun now leads the daughters, while Niger leads the mothers until the circles merge into one" (79). The rhythmical physical movements ranging from gesturing to body movement are utilized to deliver the message that youth, aided by the old generation, are capable of restoring balance to their community and it is "Youths [who] lead the people's song, and provoke them into dialogue with the audience" (1). By this means, Onwueme urges the audience to think critically and decide for themselves.

The play comes to an end when the masses, championed by women and youth, are mobilized to voice their wrath because Shell and other global oil companies, that act as their 
neo-colonial masters, manipulate the natural resources of their land and give them nothing in return except suffering and humiliation. Stage directions describe youths' rebellion, "With spotlights on them in this call-response chant, the rousing drumbeats empower the women and youths into a huge orchestra as they shift out of the stage and into the audience, to build into a communal dance-party until floodlights" (116). By positioning and grouping the actors in a way that reveals interrelationships and merges them with the audience, Onwueme calls upon her audience to celebrate people's resilience, value human agency and subjectivity and revolt against political and social corruption. Her main strength as a playwright lies in her positive call for joint action to improve the social conditions.

To conclude, as an iconic literary figure in Africa, Onwueme resorts to the cultural richness of the past to reform the present by employing the concept of Afrocentricity and reviving the indigenous Igbo traditional heritage. The Igbo tradition has multiple dramatic aspects manipulated in Then She Said It, three of which are dealt with in this paper: First, the structure of the dramatic 
performance that starts with the Igbo masquerade dance and the entrance song, followed by the 'revues' and the 'finale'. It provides the dramatist with a means to represent the ongoing socio-political events of Nigeria within the structure of the traditional Igbo performance. Second, Onwueme manipulates characters' names that carry cultural implications, reveal the veneration of the ancestors and reflect characters' identities. Third, she involves her audiences in the performance by urging them to revolt against neo-imperial oppressive power structure. These techniques are utilized as a tool to confront Western hegemony and assert Africans' identity. Through reconnecting Africans to their spiritual practices, ideals, norms and past traditions, Onwueme places them at the centre without disregarding the Eurocentric tradition. Through Onwueme's innovative manipulation of the Igbo tradition, an African experience has been presented in its potential for fundamental transformation from victimization to agency and collective liberation. 


\section{Works Cited}

Adedeji, Joel. "The Origin and Form of the Yoruba Masque Theatre". Cahiers d'Etudes Africaines, Vol. 12, Cahier 46, 1972, pp. 254-276.

Affiah, Uwem. Protest, Resistance and Activism in the drama of Osonye Tess Onwueme. American Journal of Social Issues \& Humanities, Vol. 2, No.5, Sept. 2012, pp.284-293.

Amaefula, Rowland Chukwuemeka. "Gendered Performance, Fluid Identities and Protest in Tess Onwueme's Then She Said It". Journal of Language and Cultural Education, Vol. 7, No.1, 2019. http://www.content.sciendo.com

DOI: 10.2478/jolace-2019-0008

Aniakor, Chike C. The Igbo Ijele Mask. African Arts, UCLA James S. Coleman African Studies Center, Vol. 11, No. 4, Jul., 1978, pp. 42-47. Jstor: http://www.jstor.com/stable/3335343

Asante, Molefi Kete. The Afrocentric Idea. Temple University Press, 1987.

Brennen, Tim. "On the Meaning of Personal Names: A View from Cognitive Psychology". The American Name Society, Vol. 48, No.2, June 2002, pp. 139-146.

(THE REVIVIFICATION OF INDIGENOUS ... )Dr. Aml Ibrahim 933 
Chukwuokolo, J.C. "Afrocentrism or Eurocentrism", New Journal of African Studies, 2009.

Early, G., WJ Moses, L Wilson and MR Lefkowitz . "Symposium: Historical Roots of Afrocentrism", Academic Questions, Vol.7, No.2, 1994, pp. 44-54.

Emenanjo, Ernest. The Rise of the Igbo Novel. Oxford UP, 1978.

France, Anna Kay and P.J. Corso, International Women Playwrights: Voices of Identity and TransformationProceedings of the First International Women Playwrights Conference. October 18-23, Metuchen, 1988.

Goyal, Yogita. Romance, Diaspora, and Black Atlantic Literature, Cambridge University Press, 2010.

Jeremiah, Samuel. The Niger Delta Violence, Women and Ecofeminism". Research on Humanities and Social Sciences, Vol.4, No.13, 2014.

Karenga, Maulana . Black Studies and the Problematic of a Paradigm: The Philosophical Dimension. Journal of Black Studies, Vol. 18, No. 4, 1988, pp. 395-414.

Mazama, Ama. "The Afrocentric Paradigm: Contours and Definitions". Journal of Black Studies, Vol. 31, No. 4, March, 2001, pp. 387-405.

(THE REVIVIFICATION OF INDIGENOUS ... )Dr. Aml Ibrahim 934 
Nixon, Rob. Slow Violence and the Environment of the Poor, Harvard University Press, 2011.

Nwachukwu-Agbada,"Tess Onwueme: Dramatist in Quest of Change", World Literature Today: A Literary Quarterly of the University of Oklahoma , Summer, 1992, Vol. 66, No.3, p. 467.

Odon, Glenn. Yoruba Performance, Theatre and Politics: Staging Resistance, Palgrave Macmillan, 2015.

Okodo, Ikechukwu. African Traditional Drama: The IgboNigerian Experience. Journal of Emerging Trends in Educational Research and Policy Studies (JETERAPS), Vol. 3, No.2, 2012, pp. 131-136,

Onwueme, Tess. "The Broken Calabash: an Interview with Nubia Kai, City Arts Quarterly, Vol.1, No.3, Fall 1988.

---, Then She Said It. African Heritage Press, 2002.

---, Three plays: The broken calabash, parables for a season, the reign of Wazobia. Wayne State University Press, 1993.

--- "Visions of Myth in Nigerian Drama: Femi Osofisan versus Wole Soyinka." Canadian Journal of African Studies, Vol. 25, No. 1, 1991, pp. 58-69.

(THE REVIVIFICATION OF INDIGENOUS ... )Dr. Aml Ibrahim 
Stikkers, K.W. "An outline of methodological Afrocentrism, with particular application to the thought of W.E.B. DuBois", Journal of Speculative Philosophy, Vol.22, No.1, 2008, pp. 40-49.

Uchendu, Victor C. The Igbo of Southeast Nigeria. Holt, Rinehart and Winston, 1965.

Uzoji, Emmanuel. Eco-literacy and the Planetary Crisis: Nigerian Protest Drama and the Niger-Delta Dynamics. Covenant Journal of Language Studies (CJLS) Vol. 2, No. 2. December, 2014. 